\title{
Diabetes a risk for antimicrobial resistance?
}

\author{
Vasavi Gedela ${ }^{1}$, Sree Lakshmi Gosala ${ }^{2 *}$
}

${ }^{1}$ Department of Pharmacology, ASRAMS, ELURU, Andhra Pradesh, India

${ }^{2}$ Department of Pharmacology, Rangaraya Medical College, Kakinada, East Godavari, Andhra Pradesh, India

Received: 14 October 2017 Accepted: 25 October 2017

\section{*Correspondence to:}

Dr. Sree Lakshmi Gosala, Email: sreeharish28@gmail.com

Copyright: (c) the author(s), publisher and licensee Medip Academy. This is an openaccess article distributed under the terms of the Creative Commons Attribution NonCommercial License, which permits unrestricted noncommercial use, distribution, and reproduction in any medium, provided the original work is properly cited.

\begin{abstract}
Background: Diabetic foot infections can cause substantial morbidity. The role of Diabetes mellitus in the antimicrobial resistance of pathogens in patients with foot infections is not well clarified. So, we compared the profile of antibiotic resistance in diabetic and non-diabetic foot ulcer infections. Objectives were to compare the antimicrobial resistance pattern in diabetic and non-diabetic lower limb infections.
\end{abstract}

Methods: T Pus was isolated in 50 Diabetic and 50 non-diabetic foot ulcer infections. The organisms were isolated on specific media and antibiotic susceptibility was done by using Kirby-Bauer disc diffusion method.

Results: The most frequent causative organism in diabetic and non-diabetics is Pseudomonas $27.5 \%$ vs $27.1 \%$, Staphylococcus $24.1 \%$ vs $27.1 \%$, Klebsiella $24.1 \%$ vs $22.03 \%$, E. coli $10.3 \%$ vs $10.16 \%$, Proteus $5.17 \%$ vs $5.08 \%$. No significant differences in resistance rates to Amikacin, Penicillin, Ofloxacin, Vancomycin, Piperacillin + Tazobactum were observed between diabetic and non-diabetic patients. There is significant difference in resistance to Ampicillin $(\mathrm{p}=0.017)$.

Conclusions: Diabetes per se does not seemto influence the susceptibility pattem to antimicrobials in our group of patients with foot ulcer infections.

Keywords: Ampicillin resistance, Anti-microbial resistance, Antibiotic susceptibility, Diabetes, Foot ulcer, Kirby-Bauer disc diffusion method, Nondiabetics, Pseudomonas

\section{INTRODUCTION}

Magnitude of diabetes mellitus is increasing globally at an alarming rate. About 150-170 million populations are suffering from this disease worldwide and the prevalence of diabetes will be double by 2025 as per WHO reports. ${ }^{1}$ Diabetic foot lesions are a major medical, social, and economic problem and are the leading cause of hospitalization for patients with diabetes. Infectious agents are associated with amputation of the infected foot if not treated promptly. Proper management of these infections requires appropriate antibiotic selection based on culture and antimicrobial susceptibility results; however, initial management comprises empirical antimicrobial therapy, which is often based on susceptibility data extrapolated from studies performed on general clinical isolates. ${ }^{2}$ Higher antibiotic resistance rates in diabetic patients compared with those without DM have been reported in some studies. In Indian outpatients with chronic wounds, most $(70 \%)$ antibiotic-resistant bacteria were isolated from diabetic patients. ${ }^{3}$ Bacterial resistance often results in treatment failure, which can have serious consequences. Resistant bacteria may also spread and become broader infection-control problems, not only within healthcare institutions, but in communities as well. ${ }^{4}$ Finally, with respect to the cost-containment pressures of today's healthcare environment, antibacterial drug resistance places an added burden on healthcare costs, although its full economic impact remains to be determined. ${ }^{5}$ 
The present study was conducted to 1. Compare the microbiological profile in diabetic and non-diabetic foot ulcer patients. ${ }^{2}$ Compare the antibiotic resistance pattern in diabetic and non-diabetic foot ulcer patients.

\section{METHODS}

Patients of either sex aged between 18-55 years who had come to surgery out-patient department with foot ulcer at Government general hospital, Kakinada were selected for this study. Prior permission was taken from the institutional Ethics committee to conduct the study.

It is a prospective observational comparative study. Study period: From October 2012 to December 2012. i.e. 3 months. After screening of 160 patients, 100 patients who fulfil inclusion criteria were recruited after giving the informed consent form.

\section{Inclusion criteria}

Patients aged >18yrs and <55yrs, of either sex was included. 2. Patients who were diagnosed with diabetes within 5 years. 3. Diabetic patients presented with foot infections and had not received antibiotics were included.

\section{Exclusion criteria}

Patients who already had undergone skin grafting were not included in this study.

\section{Sample collection}

From each patient a swab was collected. The sterile cotton tipped swabs were moistened with sterile saline before collecting specimens. The swabs were collected from the depth of ulcers on the feet of diabetic patients. After sampling all the specimens were processed immediately in the laboratory. For is olation of aerobic bacteria, the media used were $5 \%$ horse blood agar and MacConkey agar, which were incubated at $37^{\circ} \mathrm{C}$ for 24 hours. The organisms isolated were identified using standard methods. All the isolated were subjected to antibiotic susceptibility testing on Mueller Hinton agar using Kirby-Bauer disc diffusion method. Statistical software: SPSS22.0 was used for analys is of the data.

\section{RESULTS}

Of the 50 diabetic foot ulcer patients studied, 32 were male and 18 were female. Of the non-diabetic foot patients, 35 were male and 15 were female.

\section{Microbial organisms}

Among 50 diabetic foot infection patients, 43 cases were monobacterial, 7 cases were polybacterial. Among nondiabetic foot patients, 41 were monobacterial and 9 were polybacterial.
The organisms found in diabetic foot patients are E. coli, Staphylococcal aureus, Klebsiella, Pseudomonas, Proteus, Acinetobacter. The organisms found in nondiabetic foot patients E. coli, Klebsiella, Pseudomonas, Proteus, Acinetobacter, Staphylococcal aureus, Providentia, Citrobacter, CONS (Coagulase Negative Staphylococci).

On comparis on of organisms in both groups, Pseudomonas $27.5 \%$ vs $27.1 \%$, Staphylococcus $24.1 \%$ vs $27.1 \%$, Klebsiella $24.1 \%$ vs $22.03 \%$, E. coli $10.3 \%$ vs $10.16 \%$, Proteus $5.17 \%$ vs $5.08 \%$.

Table 1: Sex distribution.

\begin{tabular}{|lll|}
\hline & Diabetics & Non-diabetics \\
\hline Males & 32 & 35 \\
\hline Females & 18 & 15 \\
\hline
\end{tabular}

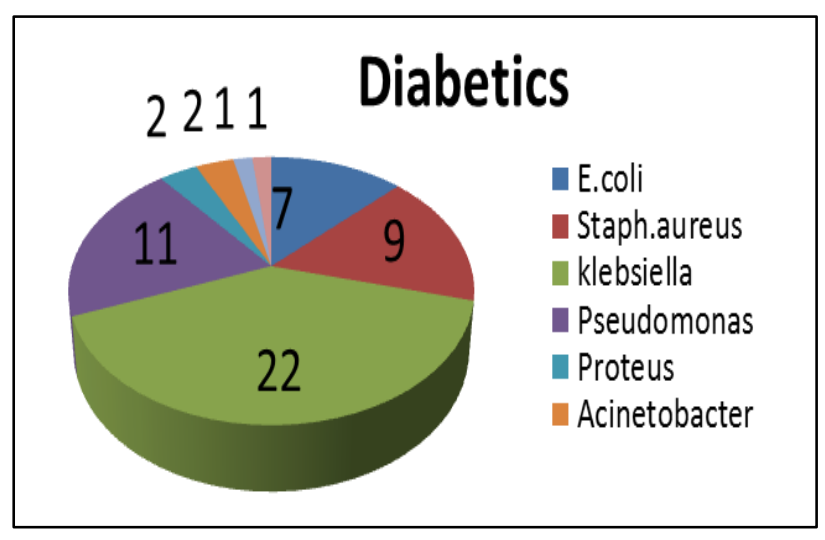

Figure 1: Distribution of organisms in diabetic and non-diabetic foot patients.

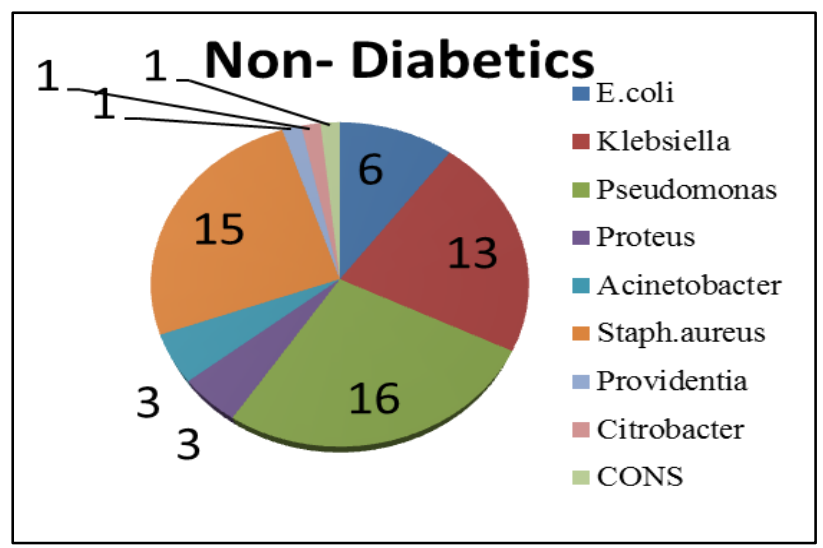

Figure 2: Comparison of antibiotic resistance in diabetic and non-diabetic foot patients.

\section{DISCUSSION}

Diabetes is the major cause of non-traumatic limb amputation. ${ }^{6}$ Several immune defence mechanisms are defective in diabetic patients. Among these are a decrease 
in leukocyte chemotaxis, phagocytosis, and intracellular killing. ${ }^{7-9}$

This study presents a comparison of microbiological pattern and antibiotic resistance in diabetic and nondiabetic foot infections.
Among the diabetic foot infection patients, gram negative organisms were predominant (Klebsiella -22, Pseudomonas -11). Our results are in tune with a similar study from the southern parts of India, which also showed that gram-negative were more common than gram-positive bacteria in diabetic foot infections. ${ }^{10}$

Table 2: Comparison of antibiotic resistance in diabetic and non-diabetic foot patients.

\begin{tabular}{|c|c|c|c|c|c|c|c|}
\hline & \multicolumn{3}{|c|}{ Diabetic patients } & \multicolumn{4}{|c|}{ Non-diabetic patients } \\
\hline Antimicrobials & Tested & Resistant & $\%$ & Tested & Resistant & $\%$ & $P$ value \\
\hline Amikacin & 44 & 20 & 45.45 & 26 & 11 & 42.30 & \\
\hline cotrimoxazole & 23 & 19 & 82.60 & 43 & 26 & 60.46 & \\
\hline Gentamicin & 30 & 13 & 43.33 & 14 & 2 & 14.28 & 0.0894 \\
\hline Linezolid & 8 & 0 & 0 & 19 & 2 & 10.52 & 1 \\
\hline Ofloxacin & 31 & 8 & 25.80 & 42 & 11 & 26.19 & 1 \\
\hline$* \mathrm{P}+\mathrm{T}$ & 11 & 2 & 18.18 & 12 & 7 & 58.33 & 0.0894 \\
\hline Penicillin & 20 & 19 & 95 & 19 & 12 & 94.73 & 1 \\
\hline Vancomycin & 9 & 0 & 0 & 18 & 3 & 16.16 & 0.5292 \\
\hline Ampicillin & 34 & 33 & 97.05 & 26 & 19 & 73.07 & 0.0164 \\
\hline Ceftriaxone & 31 & 18 & 58.06 & 39 & 19 & 48.71 & 0.477 \\
\hline Ceftazidime & 16 & 11 & 68.75 & 7 & 6 & 85.71 & 0.6214 \\
\hline${ }^{*} \mathrm{C}+\mathrm{S}$ & 30 & 0 & 0 & 11 & 3 & 27.27 & 0.0155 \\
\hline Cephalexin & 3 & 1 & 33.33 & 7 & 3 & 42.85 & 1 \\
\hline Taxim & 14 & 9 & 64.28 & 19 & 10 & 52.63 & 0.7228 \\
\hline Azithromycin & 4 & 2 & 50 & 14 & 7 & 50 & 1 \\
\hline
\end{tabular}

*P+T $=$ Piperacillin + Tazobactum, $\mathrm{C}+\mathrm{S}=$ Cefaperazone+ Sulbactum

Among the non-diabetic foot infection patients, Pseudomonas, Staphylococcal, Klebsiella organisms were found to be predominant. In our study, diabetic foot infection patients were more resistant to Ampicillin (97.05\%), Penicillin (95\%), Co-trimoxazole (82.60\%), Ceftazidime $(68.75 \%)$, Taxim $(64.28 \%)$.

Non-diabetic foot infection patients were more resistant to Penicillin (94.73\%), ceftazidime (85.71\%), Ampicillin (73.07\%), Co-trimoxazole $(60.46 \%)$. The high rates of antibiotic resistance observed in the present study may be due to the fact that ours is a tertiary care hospital with widespread usage of broad spectrum antibiotics leading to selective survival advantage of pathogens.

On comparison of antibiotic resistance pattern in both groups, there is significant difference only in Ampicillin and Cefaperazone + Sulbactum. There is no significant difference in other antibiotics resistance pattern. Our study results correlate with another study which compared resistance pattern in urinary tract infections in diabetic and non-diabetic women. ${ }^{11}$ So in our study, diabetes per se is not a risk factor for antibiotic resistance pattern.

When choosing an antimicrobial for the treatment of diabetic foot infections, one should consider the spectrum of causative organisms, their resistant patterns, efficacy, and safety. Awareness of the causative organisms in diabetic foot infections and their antimicrobial susceptibility pattern is essential for the institution of antimicrobial therapy.

Limitations of the study were anaerobic bacteria could not be assessed so we could describe the results of only aerobic bacteria.

\section{CONCLUSION}

Gram-negative organisms were more predominant in diabetic foot ulcer patients where as both gram positive and gram-negative organisms were found in the nondiabetic foot ulcer patients. Antibiotic resistance pattem when compared in both groups, there is no significant difference in diabetics and non-diabetics. So, in our study, Diabetes per se did not influence the susceptibility pattem of antimicrobials.

\section{ACKNOWLEDGEMENTS}

Authors would like to thank all our teachers who guided them throughout the study. Also, authors sincerely thank to the patients who co-operated. 
Funding: No funding sources

Conflict of interest: None declared

Ethical approval: The study was approved by the Institutional Ethics Committee

\section{REFERENCES}

1. WHO. Prevention and control of Diabetes Mellitus, Report of an Inter country workshop, Dhaka, Bangladesh; 1998:27-30. April 1998, SEA/NCD/40.

2. Goldstein EJ, Citron DM, Nesbit CA. Diabetic foot infections: bacteriology and activity of 10 oral antimicrobial agents against bacteria isolated from consecutive cases. Diabetes care. 1996;19(6):638-41.

3. Basu S, Ramchuran PT, Bali ST, Gulati AK, Shukla VK. A prospective, descriptive study to identify the microbiological profile of chronic wounds in outpatients. Ostomy/wound management. 2009;55(1):14-20.

4. Tenover FC. Mechanisms of antimicrobial resistance in bacteria. The American journal of medicine. 2006;119(6):S3-10.

5. McGowan JE, Jr. Economic impact of antimicrobial resistance. Emerg Infect Dis. 2001;7:286-92.

6. Gibbons GW, Eliopoulos GM. Infection of the diabetic foot. In: Kozak GP, Hoar GS, Rowbottam JL,
Wheelock FC, Campel D, editors. Management of diabetic foot problems. Philadelphia (USA): WB Saunders; 1984:97-102.

7. Mowat A, Baum J. Chemotoxis of polymorphnuclear leucocytes from patients with diabetes mellitus. N Eng1 J Med. 1971;284:621-7.

8. Bybee JD, Rogers DE. The phagocytic activity of polymorphnuclear leucocytes obtained from patients with diabetes mellitus. J Lab Clin Med. 1964;64:1-13.

9. Tan JS, Anderson JL, Watanakunakorn G, Phair JP. Neutrophil dysfunction in diabetes mellitus. J Lab Clin Med. 1975;85:26-33.

10. Shankar EM, Mohan V, Premalatha G, Srinivasan RS, Usha AR. Bacterial etiology of diabetic foot infections in South India. EFIM. 2005;16(8):567-70.

11. Diabetes mellitus in itself is not a risk factor for antibiotic resistance in Escherichia coli isolate from patients with bacteriuria. Meiland R, Geerlings SE, De Neeling AJ, Hoepelman AI. Diabet Med. 2004;21(9):1032-4.

Cite this article as: Gedela V, Gosala SL. Diabetes a risk for antimicrobial resistance?. Int J Basic Clin Pharmacol 2017;6:2811-4. 